\title{
THE EFFECT OF CUTTING PARAMETERS ON SURFACE INTEGRITY IN MILLING TI6AL4V
}

\author{
G.A. Oosthuizen ${ }^{1}$, K. Nunco ${ }^{2}$, P.J.T. Conradie ${ }^{1 *}$ \& D.M. Dimitrov ${ }^{1}$
}

\section{ARTICLE INFO}

Article details

Submitted by authors 11 Mar 2015

Accepted for publication 8 Aug 2016

Available online 6 Dec 2016

Contact details

* Corresponding author

pjtconradie@gmail.com

Author affiliations

1 Department of Industrial Engineering, Stellenbosch

University, South Africa

2 Department of Mechanical Engineering Science, University of Johannesburg, South Africa

DOI

http: //dx.doi.org/10.7166/27-4-1199
ABSTRACT

The objective of machining performance is to reduce operational costs and to increase the production rate while maintaining or improving the required surface integrity of the machined component. Together with industrial partners, several benchmark titanium components were selected and machined to achieve this. Titanium alloys are used extensively in several industries due to its unique strength-to-weight ratio and corrosion resistance. Its properties, however, also make it susceptible to surface integrity damage during machining operations. The research objectives of this study were to understand the effect of cutting parameters on surface integrity to ensure that machined components are within the required surface quality tolerances. The effect of cutting speed and feed rate on surface roughness, micro-hardness, and the microstructure of the work piece were studied for milling Ti6Al4V. The surface roughness increased with a greater feed rate and a decrease in cutting speed. The maximum micro-hardness was 23 per cent harder than the bulk material. Plastic deformation and grain rotation below the machined surface were found with the rotation of the grain lines in the direction of feed. There was no evidence of subsurface defects for any of the cutting conditions tested.

\section{OPSOMMING}

Die masjineringsvermoë doelwit bly steeds om operasionele kostes te verminder en om die produksietempo te verhoog, terwyl die vereiste oppervlakafwerking van die komponent gehandhaaf of verbeter word. Ten einde hierdie doelstelling te bereik is verskeie komponente in samewerking met industrievennote, as maatstaaf komponente gekies en gemasjineer. Titaan allooie word op groot skaal in verskeie industrieë gebruik vanweë sy unieke sterkte-totdigtheid verhouding en korrosiebestandheid. Hierdie eienskappe maak die allooi egter ook vatbaar vir oppervlakafwerking skade tydens die masjineringsproses. Die navorsingsdoelstelling van hierdie studie was om die effek van die snyparameters op die oppervlakafwerking te verstaan, om sodoende te verseker dat die komponente binne die vereiste oppervlak toleransies vervaardig word. Die effek van snyspoed en voertempo tydens freeswerk op die oppervlak grofheid, mikrohardheid en mikrostruktuur van die Ti6Al4V werkstuk is bestudeer. Die oppervlakgrofheid het verhoog met ' $n$ toename in voertempo en vermindering in snyspoed. Die maksimum mikrohardheid was 23 persent harder as die basismateriaal. Plastiese vervorming en korrel rotasie onder die gemasjineerde werkstuk oppervlak is gevind met die korrelgrein in die rigting van die voer. Daar was geen aanduiding van suboppervlak defekte onder enige van die toets kondisies nie. 
The efficiency and cost-effectiveness of machining processes can be improved either by increasing the process speed to produce more components in a certain time span, or by reducing the cycle time per component. Although manufacturers aim to understand the combined effects of cutting strategies and parameters on the maximum production rate and minimum total cost per part, it is also critical to maintain or improve the required surface integrity of the machined components. The competitive advantage is embedded in the ability to manufacture parts at a production rate faster than planned, at a cost lower than predicted, and with part-quality better than specified, to enhance resource efficiency (see Figure 1 ). To assist process planners and machine operators to achieve this working towards optimised machining processes, a cost-modelling process-planning framework has been constructed. Several input drivers that have an influence on the efficiency and cost of a manufacturing system form part of the framework. These drivers must be managed in a way that can optimise the internal processes to manufacture parts competitively. Within this framework, surface integrity plays a vital role as one of the competitiveness indicators.
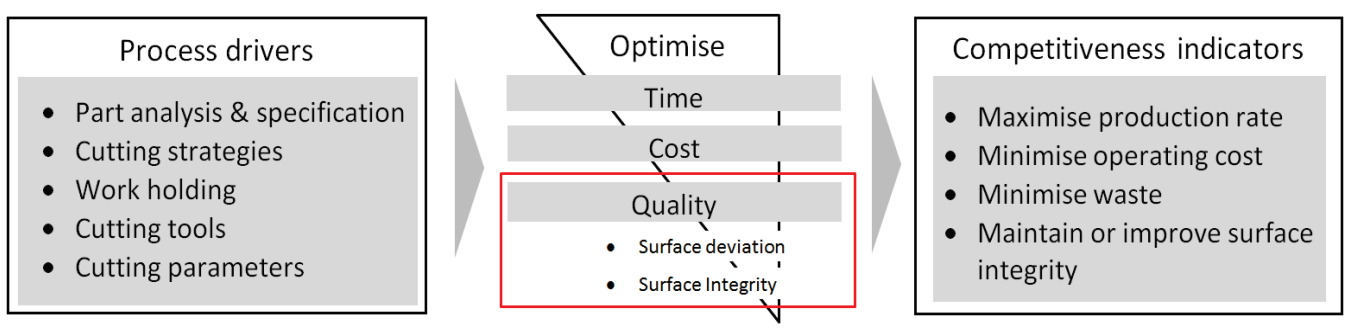

Figure 1: Key elements to enhance resource efficiency of a machining process (for illustrative purposes only)

Extensive research has been done on the economic optimisation of cutting in terms of process parameters, time, and cost $[1,2,3]$. These studies did not, however, include the effect of the optimisation procedure on the surface integrity of the machined work piece. This study therefore aims to understand the effect of different cutting parameters, as part of the machining strategies, on the surface integrity of titanium components. It has been reported that the surface integrity of titanium alloys can easily be damaged during machining processes due to the thermal properties of the alloy [4]. A low thermal conductivity prevents heat from dissipating, concentrating a large amount of heat in the cutting zone, which thus becomes one of the main sources of damage [5]. The toughness and chemical reactivity of titanium at high temperatures are further sources of damage to the material surface [6]. The production of heat-affected zones, plastic deformation, redeposited material, and cavities are typical indicating factors [7]. These defects propagate to form micro-cracks that, under load, can progress to core or critical sections causing sudden failure [8]. As a result, surface integrity analysis forms an integral part of performance measurements for aerospace components. In this study, therefore, the cutting conditions of selected titanium demonstrator components were replicated to evaluate the effect on surface integrity and final part quality.

\section{MACHINING CHALLENGES}

Titanium alloys are used comprehensively in the aerospace, automotive, biomedical, and chemical industries due to the alloys' unique properties. However, some of the properties (including low modulus of elasticity, high chemical reactivity, and low thermal conductivity) contribute to the alloys' machining challenges. These can be divided into thermal and mechanical demands; their respective influences are summarised below [9].

Thermal demands include both thermal loading and shock as the two main temperature influencing factors. Thermal loading relates to the increase of the tool face temperature, which is attenuated by the low thermal conductivity of titanium. This is, furthermore, linked to the exposure time, which can be defined as the duration that the tool material is exposed to the critical temperature at a certain depth below the surface [10]. Thermal shock is a potentially catastrophic stress that occurs in a material from extreme temperature fluctuations that can result in thermal fatigue. As the cutting tool enters and exits the work piece, it is subjected to force fluctuations, together with cyclic heating and cooling, that can lead to abrupt tool failure [11]. 
Mechanical demands relate to the influence of vibration and chatter and the forces induced by the cutting process. Komanduri and Hou [12] reported that catastrophic tool failure through chipping is caused by pulsating loads from plastic deformation in the shear bands between the chip segments, self-induced chatter, and fluctuating cutting forces produced during the milling operation. Efficient cutting strategies and parameters therefore play a critical role in managing the tool engagement and demands imposed as a result. Improved stiffness provided by an efficient work-holding setup is also important to reduce the combined effects of the mechanical demands inflicted by the cutting process [11].

Surface integrity can be defined as the surface condition of a material after being altered by a specific manufacturing process. The manufacturing process consists of several steps (see Figure 2), of which the effects of optimisation processes along the manufacturing chain will ultimately affect the surface integrity of the part. It is important, therefore, to understand the effect of changing parameters on different aspects of surface integrity. This is a well-researched area, and much work has been done to encompass a great variety of approaches and techniques to determine the state of the material after manufacture [4, 5, 7, 8, 12]. In general, it involves investigating the surface roughness, metallurgical changes, micro-hardness, and the residual stresses of the machined work piece [13]. However, in the current study the selected evaluation criteria only included surface roughness, microstructure, and micro-hardness. Residual stresses were not analysed due to geometric considerations, and thus need to form part of future work.

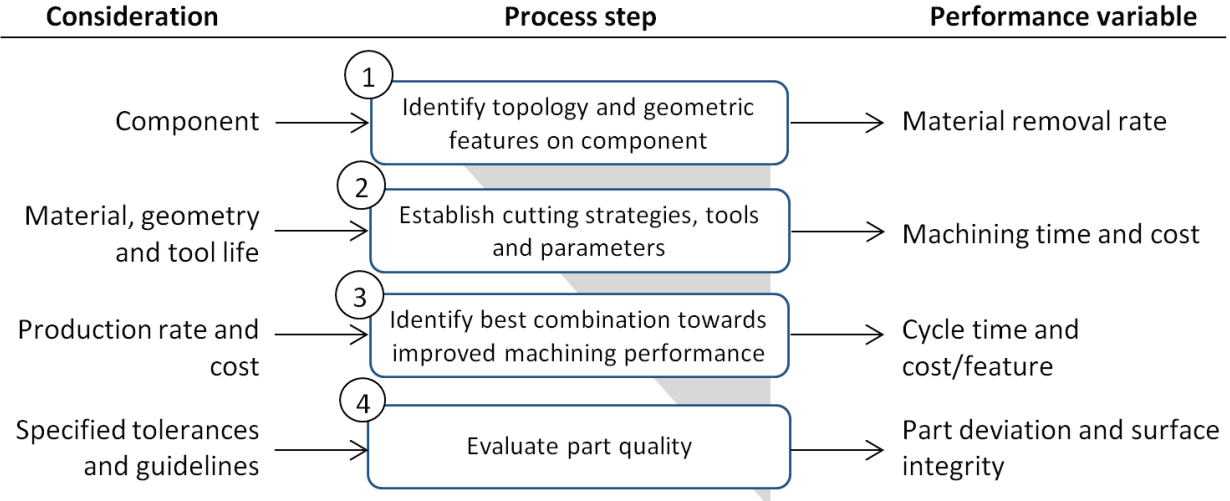

Figure 2: Approach to evaluate machining performance using surface integrity analysis (for illustrative purposes only)

The surface roughness is influenced by several factors, of which the most prominent include the cutting speed, feed rate, depth of cut, tool wear, and type of cutting tool. For end milling Ti6Al4V, Sun and Guo [14] reported that the surface roughness in the feed direction increased with higher feed rates. Conversely, the roughness value decreased with an increasing cutting speed in the feed direction. Yang et al. [15] observed that the surface roughness initially decreased, and then increased for cutting speeds in the range of 80 to $140 \mathrm{~m} / \mathrm{min}$. Che-Haron and Jawaid [16] found that the surface roughness became lower as the cutting speed was raised. Microstructure analysis involves evaluating subsurface layers to assess phase composition, grain size, grain orientation, and phase transformations induced by the cutting conditions. Experiments performed by Sun and Guo [14] revealed no changes in the $B$ phase at low cutting speeds in the range of 50 to $65 \mathrm{~m} / \mathrm{min}$. However, at higher cutting speeds in the range of 80 to $90 \mathrm{~m} / \mathrm{min}$, there was evidence of $B$ phase transformation. Yang et al. [15] reported that no observations were made on the transformation of the $B$ phase for side milling cutting speeds between 80 and $140 \mathrm{~m} / \mathrm{min}$. Li et al. [17] found that some degree of phase transformation from the $B$ phase to the a phase occurred near the surface as a result of high temperatures incurred through plastic deformation associated with the cutting process.

Micro-hardness relates to the effect and interaction of the cutting conditions on the hardness of the surface and subsurface layers. Che-Haron and Jawaid [16] found that for turning Ti6Al4V, a workhardened surface layer with hardness higher than the bulk material reached a depth of about 100 $\mu \mathrm{m}$ below the surface. The subsurface hardness immediately below the surface had a hardness value lower than the bulk material. This was confirmed by Hughes et al. [18]. A similar tendency was 
recorded by Canteroa et al. [19] in drilling Ti6Al4V: they reported a 30 per cent increase in hardness in the deformed layer near the surface.

\section{EXPERIMENTAL SETUP AND DESIGN}

New milling strategies for high performance machining (HPM), advanced cutting tools, and improved lubrication strategies for machining titanium alloys have been investigated over the last few years. In collaboration with industrial partners, specific aerospace components were selected as demonstrators to be manufactured from titanium alloys. These components, illustrated in Figures 3 and 4, have geometrical aspects commonly associated with aerospace components, such as positive and negative thin walls, undercuts, compound angles, radius sections, high material removal volume, and thin base areas.

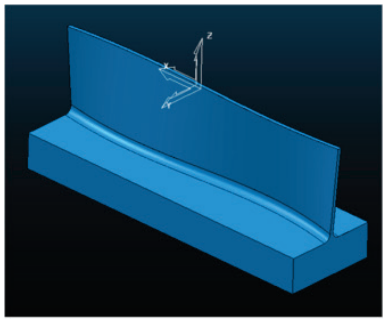

(a)

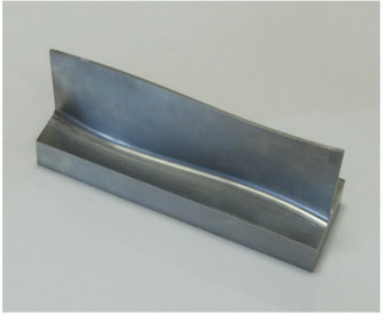

(b)

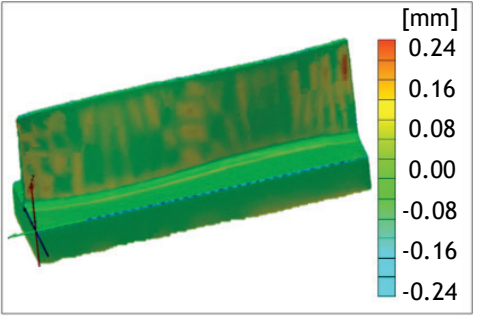

(c)

Figure 3: Demonstrator 1: S-shaped part: (a) CAD model, (b) machined component, and (c) surface deviation with geometric optical measuring equipment (see online version for colour)

With the aim of improving the machining performance, research has evaluated the effect of different cutting strategies, lubrication strategies, and tool geometries on the cutting process. Great reductions in machining time and costs have been realised [20]. Using the parameters set out in Table 1, the demonstrators were finished within the specified dimensional tolerances of 300 to $500 \mu \mathrm{m}$ for aerospace components, as shown in Figures 3(c) and 4(c).

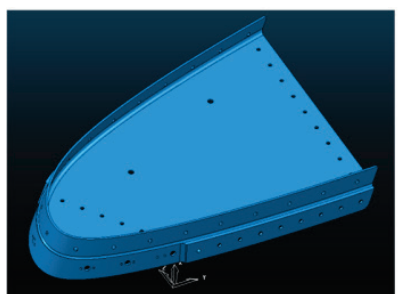

(a)

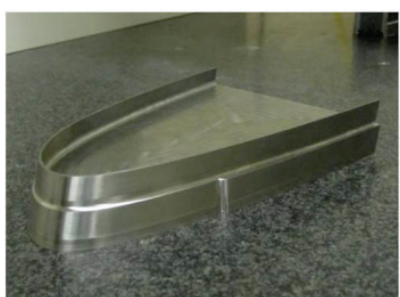

(b)

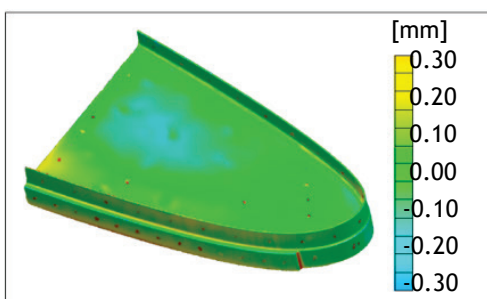

(c)

Figure 4: Demonstrator 2: Wingtip (a) CAD model, (b) machined component, and (c) surface deviation with geometric optical measuring equipment (see online version for colour)

Successful manufacturing of the demonstrators validated the process parameters, allowing replication of the cutting conditions on smaller titanium samples to enable further surface integrity analysis. The experiments were set up with fixed parameters for every trial to allow individual evaluation of each parameter. The evaluation criteria included surface roughness, hardness, and microstructure analyses for the range of parameters used to manufacture the demonstrators (see Figures 3 and 4).

Table 1: Cutting parameters used to machine the selected titanium components

\begin{tabular}{llll}
\hline \multicolumn{1}{c}{ Parameter } & Symbol & Range & Unit \\
\hline Cutting speed & $V_{c}$ & $60-80$ & {$[\mathrm{~m} / \mathrm{min}]$} \\
Feed rate & $f_{\mathrm{z}}$ & $0.3-0.6$ & {$[\mathrm{~mm} / \mathrm{z}]$} \\
Axial depth of cut & $a_{p}$ & $0.3-0.5$ & {$[\mathrm{~mm}]$} \\
Radial depth of cut & $a_{e}$ & $10-12$ & {$[\mathrm{~mm}]$} \\
\hline
\end{tabular}

The experiments for the samples were conducted on a Hurco 5-axis CNC machine (model: VMX30U). The cutting tool was a 2-flute $16 \mathrm{~mm}$ diameter Mitsubishi insert cutter fitted with two VP15TF 
carbide inserts. The lubrication strategy implemented was flood coolant with BioKool J cutting fluid from Flexilube. The cutting parameters are summarised in Table 2.

Table 2: Milling parameters of Ti6Al-V under flood lubrication

\begin{tabular}{llll}
\hline \multicolumn{1}{c}{ Parameter } & Symbol & \multicolumn{1}{c}{ Range } & Unit \\
\hline Cutting speed & $v_{c}$ & $50-90$ & {$[\mathrm{~m} / \mathrm{min}]$} \\
Feed rate & $f_{z}$ & $0.3-0.5$ & {$[\mathrm{~mm} / \mathrm{z}]$} \\
Axial depth of cut & $a_{p}$ & 0.5 & {$[\mathrm{~mm}]$} \\
Radial depth of cut & $a_{e}$ & 12 & {$[\mathrm{~mm}]$} \\
\hline
\end{tabular}

The surface roughness was investigated on a Hommel Etamic (model: T8000) surface roughness tester. The milled samples were mounted using a Leco hot mounting press (model: PR-25), and grinding and polishing were done using the Struers LaboPol-25 series. Micro-hardness analyses were performed with a Vickers micro-hardness tester, and the microstructure analysis was done with a metallurgical microscope after etching with Kroll's etching agent. Tool wear analyses were performed using a stereo microscope (Olympus SZX16) with analysis software.

\section{EXPERIMENTAL RESULTS AND DISCUSSION}

The surface roughness $\left(R_{a}\right)$ of the machined surface was measured for each titanium sample. The influence of the cutting speed $\left(v_{c}\right)$ and the feed rate $\left(f_{z}\right)$ on the surface roughness is illustrated in Figure 5.

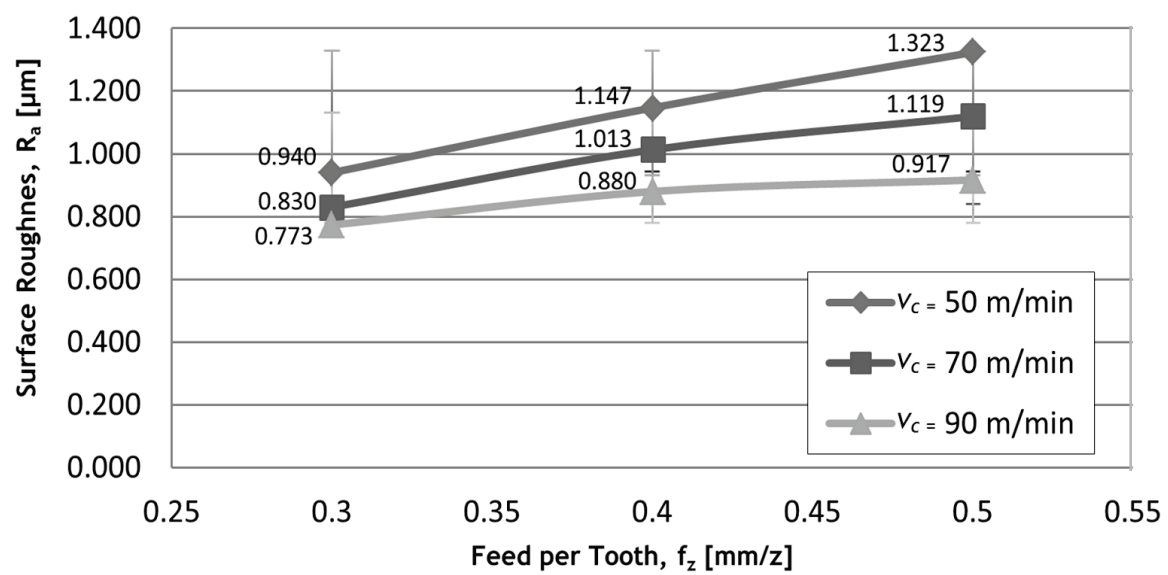

Figure 5: Influence of cutting speed and feed rate on the surface roughness of Ti6Al4V

From these results it can be seen that the surface roughness value $R a$ of the titanium samples decreases as the cutting speed is increased. This is due to a reduced plastic deformation cutting zone incurred by a higher cutting speed. The surface defect is therefore smaller, leading to an overall lower roughness value. This corresponds with the results of Yang et al. [15] who conducted similar experiments on titanium. A gradual increase in surface roughness is observed when higher feed rates are implemented at constant cutting speeds. At speeds of 50,70 , and $90 \mathrm{~m} / \mathrm{min}$ the roughness values deviated by $0.383,0.289$, and $0.114 \mu \mathrm{m}$ respectively, as the feed/tooth was raised incrementally from 0.3 to $0.5 \mathrm{~mm}$. It illustrates that the surface roughness becomes less sensitive to a change in the feed-per-tooth as the cutting speed increases. This agrees with the work of Ibrahim et al. [13], who presented the roughness as a function of feed rate and nose radius. With the same radius, the roughness rises proportionally to the function that characterises the tool-work piece setup. The higher roughness is also influenced by the increased tool wear recorded with the greater feeds, as shown for the rake and flank faces in Table 3.

The main tool deterioration phenomena recorded during the experiments are flank wear, crater wear, and chipping (see Table 3). These are the result of the material properties of titanium, including low modulus of elasticity, poor thermal conductivity, chip segmentation, and chemical reactivity at elevated temperatures. The hardness values were analysed from the machined surface down to a depth of 200 microns. The results, illustrated in Figure 6, indicate the relationship of the 
cutting speed and the feed rate to the subsurface micro-hardness and depth below the machined surface. The Knoop hardness values are listed on the vertical axis, and the depth below the surface on the horizontal axis.

Table 3: Tool wear of carbide tools (VP15TF) for milling Ti6Al4V

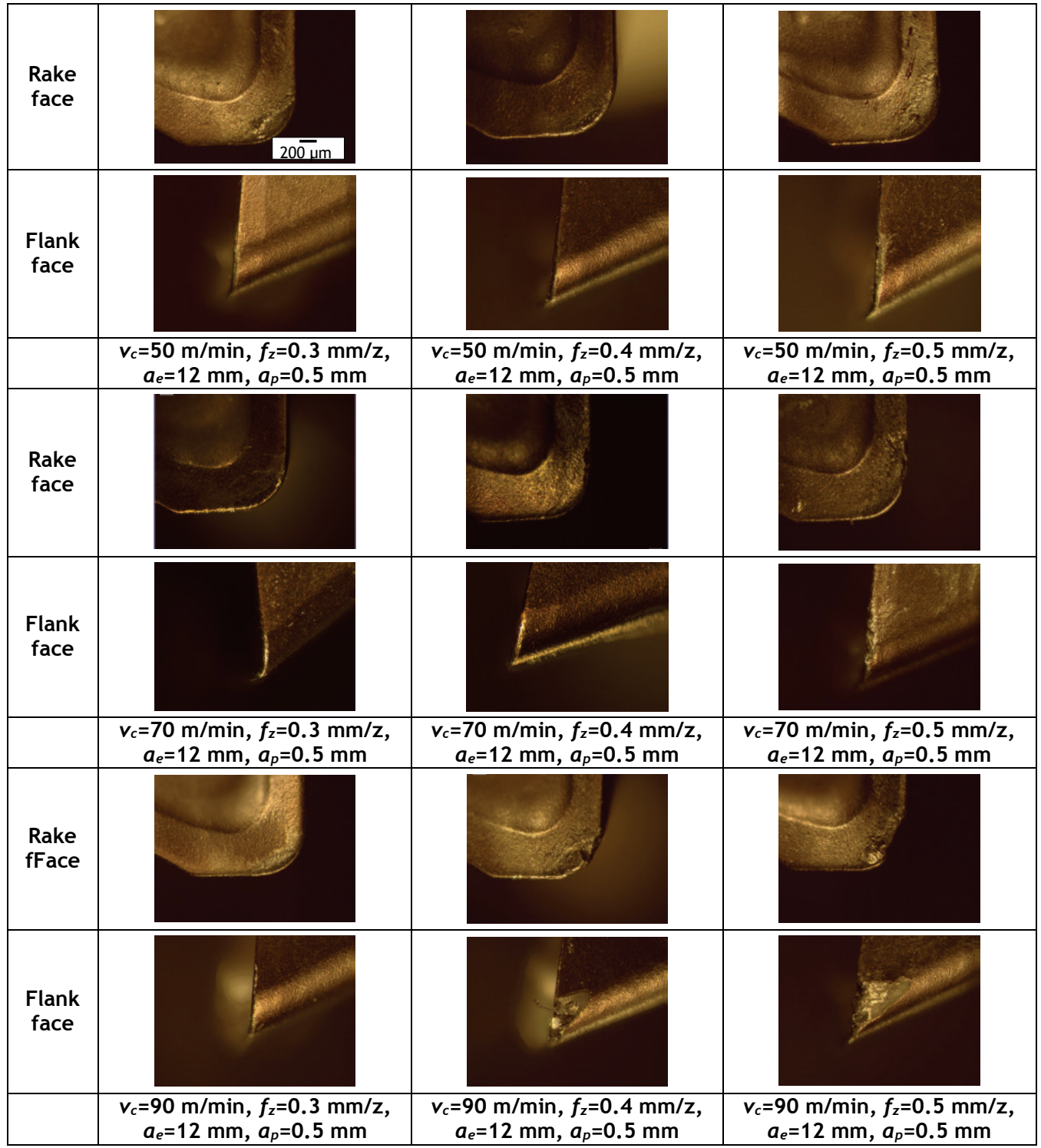




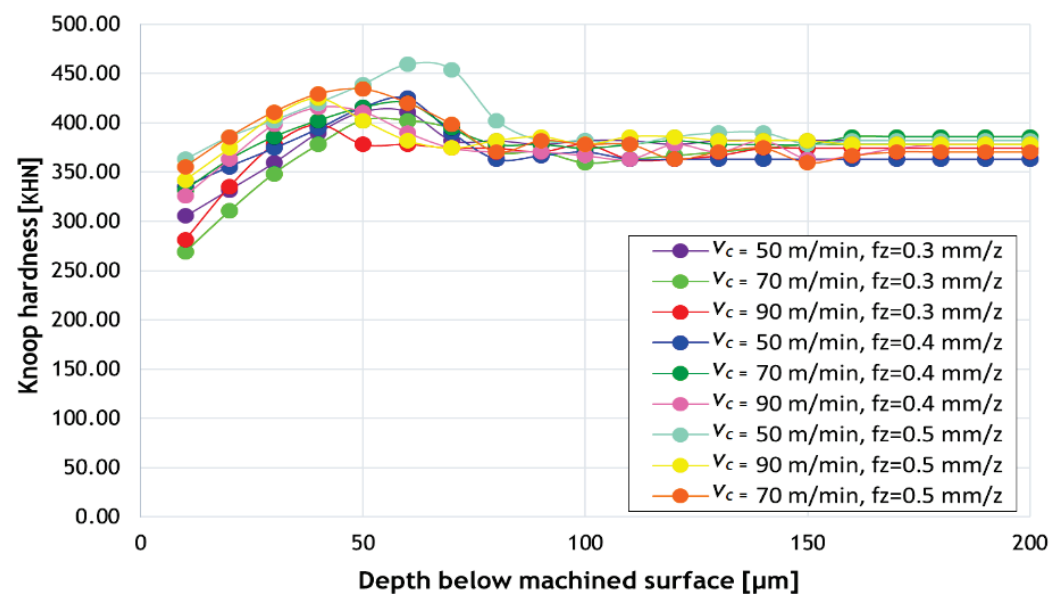

Figure 6: Influence of cutting speed and feed rate on the micro-hardness of Ti6Al4V (see online version for colour)

The poor thermal conductivity of titanium alloys and the high cutting pressures and temperatures generated in the cutting zone largely influence the micro-hardness of the material. These cutting temperatures and forces on the surface induce plastic deformation, causing instability in the microstructure to form a subsurface metallurgical alteration that results in a softer layer below the surface.

Advancing into the material, an increase in hardness was recorded from below the surface, reaching a maximum at a depth of 50 to60 $\mu \mathrm{m}$ for the various cutting speeds and feed rates. The highest recorded hardness $(455 \mathrm{KHN})$ was 23 per cent harder than the bulk material ( $370 \mathrm{KHN})$. This is due to the effect of internal work-hardening incurred by the cyclic action of the milling process. Repetitive engagements (entry and exit movements) of the milling process are associated with cyclic heating and cooling, which together with fluctuating forces affect the mechanism of internal stress relaxation. This raises the defect micro-hardness with reference to the bulk material hardness. These results were confirmed by the work of Gintini and Nouari [21] who reported similar outcomes. The graph in Figure 6 also shows that increasing the cutting speed tends to decrease the depth and extent of subsurface layer hardening. Conversely, increasing the feed rate increases the depth and magnitude of hardening due to the degree of influence of the respective parameters, as discussed earlier. The observed tendency was also confirmed by Yang et al. [15].

The microstructure images depicted in Table 4 are sections of the material perpendicular to the machined surface. Plastic deformation occurred to a depth of $21 \mu \mathrm{m}$ below the machined surface. Other than the plastic deformation, there was no evidence of subsurface defects such as cracks, laps, or visible tears under the various cutting conditions. The rotation angle of the grains and the plastic deformation below the surface tend to align in the direction of the feed as the cutting speed $\left(v_{c}\right)$ and feed rate $\left(f_{z}\right)$ increase. In addition, the volume of beta phase near the surface slightly decreases as the cutting speed and feed rate are raised. This is the consequence of higher temperatures and forces induced by the cutting parameters on the surface of the work piece. These microstructure results also correspond with the trend of micro-hardness variation presented in Figure 6.

No phase transformations, such as white layer on the machined surface, were observed. This can be attributed to the fact that the surfaces were machined with sharp tools and that well-lubricated conditions prevented temperatures that were high enough to induce these transformations. Similar results were reported by Sun and Guo [14].

\section{CONCLUSION}

The effect of cutting parameters on the surface integrity of Ti6Al4V components was investigated. Specific aerospace components were selected as demonstrators. The surface roughness decreased with an increase in cutting speed due to a smaller plastic deformation cutting zone associated with elevated speeds. The surface roughness increased with higher feed rates owing to the proportional 
ratio between cutting parameters and the higher tool wear recorded on the rake and flank faces. All the surface roughness $(R a)$ values were below the industry requirement of $1.6 \mu \mathrm{m}$. The main tool deterioration phenomena were flank wear, crater wear, and chipping. The hardness in subsequent layers increased due to internal work-hardening induced by the cyclic effects of the milling process. The maximum hardness was 23 per cent harder than the bulk material at a depth of $60 \mu \mathrm{m}$. At a depth of $90 \mu \mathrm{m}$, the hardness converged to the value of the bulk material for the various cutting speeds and feed rates tested. Plastic deformation and grain rotation below the machined surface were found up to a depth of $21 \mu \mathrm{m}$, with the rotation of the grain lines in the direction of the feed. The volume of beta phase near the surface decreased slightly with the higher speeds and feeds. No white layer defects were observed on the machined subsurface.

Table 4: Influence of cutting speed and feed rate on the microstructure of Ti6Al4V

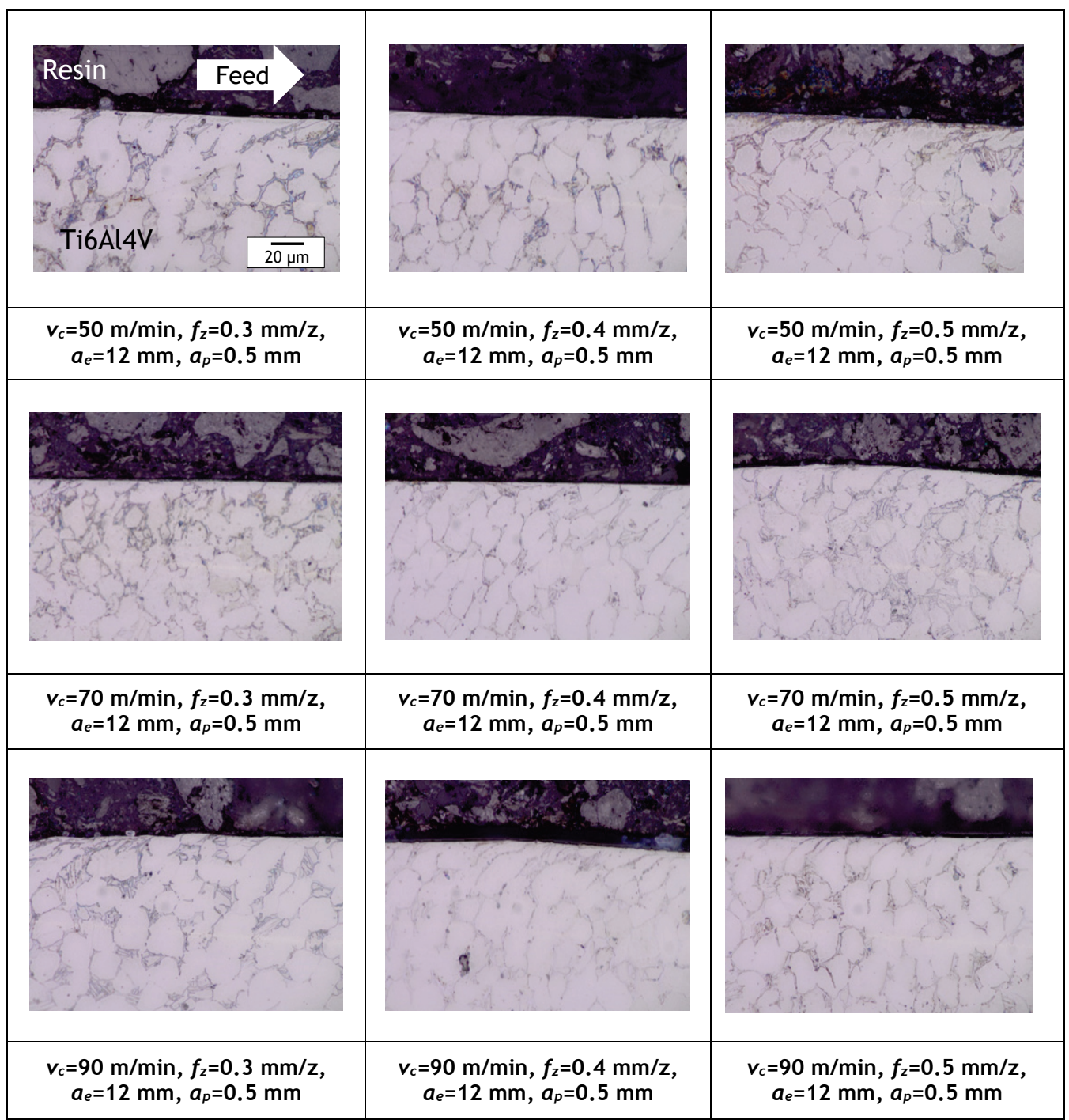

\section{ACKNOWLEDGEMENTS}

This work was funded by the South African Department of Science and Technology (DST).

\section{REFERENCES}

[1] Byrne, G., Dornfield, D. and Deneka, B. 2003. Advanced cutting technology, CIRP Annals - Manufacturing Technology, 52(2), pp 483-507. 
[2] Mativenga, P.T. and Jajemi, M.F. 2011. Calculation of optimum cutting parameters based on minimum energy footprint, CIRP Annals - Manufacturing Technology, 60, pp 149-152.

[3] Baskar, N., Asokan, P., Saravanan, R. and Prabhaharan, G. 2005. Optimization of machining parameters for milling operations using non-conventional methods, International Journal of Advanced Manufacturing Technology, 25, pp 1078-1088.

[4] Che-Haron, C.H. 2001. Tool life and surface integrity in turning titanium alloys, Journal of Materials Processing Technology, 118, pp 231-237.

[5] Field, W. and Kahles, J. 1971. Review of surface integrity of machined components, Annals of the CIRP, 20, pp 153-163.

[6] Laubscher, R.F., Styger, G. and Oosthuizen, G.A. 2014. A numerical analysis of machining induced residual stresses of grade 5 titanium alloy, $R \& D$ Journal of the South African Institution of Mechanical Engineering, 30, pp 39-46.

[7] Sharman, A.R.C., Aspinwall, D.K., Dewes, R.C. and Bowen, P. 2001. Workpiece surface integrity considerations when finish turning gamma titanium aluminide, Wear, 249, pp 473-481.

[8] Ulutan, D. and Ozel, T. 2011. Machining induced surface integrity in titanium and nickel alloys: A review, International Journal of Machine Tools \& Manufacture, 51, pp 250-280.

[9] Chunxiang, C., BaoMin, H., Lichen, Z. and Shuangjin, L. 2011. Titanium alloy production technology, market prospects and industry development, Materials and Design, 32, pp 1684-1691.

[10] Arrazola, P.-J., Garay, A., Iriarte, L.-M., Armendia, M., Marya, S. and Le Maître, F. 2009. Machinability of titanium alloys (Ti6Al4V and Ti555.3), Journal of Materials Processing Technology, 209, pp 2223-2230.

[11] Dimitrov, D.M., Conradie, P.J.T. and Oosthuizen, G.A. 2013. A process planning framework for milling of titanium alloys, International Conference on Competitive Manufacturing, Stellenbosch.

[12] Sasahara, H., Obikawa, T. and Shirakashi, T. 2004. Prediction model of surface residual stress within a machined surface by combining two orthogonal plane models, International Journal of Machine Tools and Manufacture, 44, pp 815-822.

[13] Ibrahim, G.A., Haron, C.C. and Ghani, J.A. 2009. The effect of dry machining on surface integrity of titanium alloy Ti-6Al-4V. Journal of Applied Sciences, 9(1), pp 121-127.

[14] Sun, J. and Guo, Y. 2009. A comprehensive experimental study on surface integrity by end milling Ti-6Al4V, Journal of Materials Processing Technology, 209(8), pp 4036-4042.

[15] Yang, X., Ren, C., Wang, Y. and Chen, G. 2012. Experimental study on surface integrity of Ti-6Al-4V in high speed side milling, Transactions of Tianjin University, 18, pp 206-212.

[16] Che-Haron, C. and Jawaid, A. 2005. The effect of machining on surface integrity of titanium alloy Ti-6Al4V, Journal of Materials Processing Technology, 166, pp 188-192.

[17] Li, R., Riester, L., Watkins, T.R., Blau, P.J. and Shih, A.J. 2007. Metallurgical analysis and nanoindentation characterization of Ti-6Al-4V workpiece and chips in high-throughput drilling, Material Science and Engineering: A, 472, pp 115-124.

[18] Hughes, J.I., Sharman, A.R.C. and Ridgway, K. 2004. The effect of tool edge preparation on tool life and workpiece surface integrity, Proceedings of the Institution of Mechanical Engineers, Part B: Journal of Engineering Manufacture, 218, pp 1113-1123.

[19] Canteroa, J.L., Tardiob, M.M., Cantelia, J.A., Marcosc, M. and Miguelez, M.H. 2005. Dry drilling of alloy Ti-6Al-4V, International Journal of Machine Tools and Manufacture, 45, pp 1246-1255.

[20] Conradie, P.J.T., Oosthuizen, G.A., Dimitrov, D.M. and Saxer, M. 2015. Effect of milling strategy and tool geometry on machining cost cutting titanium alloys, South African Journal of Industrial Engineering, 26(3), pp 137-151.

[21] Ginting, A. and Nouari, M. 2009. Surface integrity of dry machined titanium alloys, International Journal of Machine Tools and Manufacture, 49(3), 325-332. 